East Tennessee State University

Digital Commons @ East Tennessee State University

2014

\title{
FASB and IASB Harmonization of Leases
}

Robert G. Morgan

East Tennessee State University

Martha M. Pointer

East Tennessee State University, Pointer@etsu.edu

Gary G. Berg

East Tennessee State University, bergg@etsu.edu

Follow this and additional works at: https://dc.etsu.edu/etsu-works

Part of the Higher Education Commons

\section{Citation Information}

Morgan, Robert G.; Pointer, Martha M.; and Berg, Gary G.. 2014. FASB and IASB Harmonization of Leases. Proceedings of the Joint Meeting of the Academic Business World International Conference \& International Conference on Learning and Administration in Higher Education, Nashville, TN. 205-211.

This Conference Proceeding is brought to you for free and open access by the Faculty Works at Digital Commons @ East Tennessee State University. It has been accepted for inclusion in ETSU Faculty Works by an authorized administrator of Digital Commons @ East Tennessee State University. For more information, please contact digilib@etsu.edu. 


\section{FASB and IASB Harmonization of Leases}

\section{Copyright Statement}

This document was published with permission from the publisher. It was originally published in the Proceedings of the Joint Meeting of th Academic Business World International Conference and International Conference on Learning and Administration in Higher Education. 
FASB and IASB Harmonization of Leases

Martha M. Pointer

East Tennessee State University

Robert G. Morgan

East Tennessee State University

Gary G. Berg

East Tennessee State University

ABSTRACT

In an effort to harmonize worldwide accounting standards, the two primary parties, the Financial Accounting Standards Board (FASB) and the International Accounting Standards Board (IASB), are taking a topic-by-topic approach in an attempt to develop accounting standards that are acceptable to both bodies. Upon completion of this project, the similar accounting standards will be used worldwide. However, the harmonization of accounting standards is made more difficult by the different approaches taken toward accounting standards setting. The FASB uses a rules-based approach to standard setting while the IASB uses a principles-based approach. The current project under discussion by the two boards is one of the more difficult areas to harmonize - accounting for leases.

\section{4-Joint Meeting of the \\ International Conference on Learning and Administration in Higher Education and the International Conference of the Academic Business World}

